\title{
Trigemino-autonomic headache and Horner syndrome as a first sign of granulomatous hypophysitis

\author{
OPEN
}

Jeremias Motte, MD

Ilonka Kreitschmann-

Andermahr, MD

Anna Lena Fisse, MD

Christian Börnke, MD

Christoph Schroeder, MD

Kalliopi Pitarokoili, MD

Oliver Müller, MD

Carsten Lukas, MD

Johannes van de Nes,

$\mathrm{MD}, \mathrm{PhD}$

Rolf Buslei, MD

Ralf Gold, MD

Ilya Ayzenberg, MD

Correspondence to

Dr. Motte:

Jeremias.Motte@rub.de

Supplemental data at Neurology.org/nn

\section{ABSTRACT}

Objective: To report a rare case of incipient granulomatous hypophysitis presenting by atypical trigemino-autonomic cephalalgia (TAC) and Horner syndrome.

Methods: The patient was investigated with repeated brain MRI, CSF examination, thoracic CT, Doppler and duplex ultrasound of the cerebral arteries, and extensive serologic screening for endocrine and autoimmune markers. Written informed consent was obtained from the patient for access to clinical files for research purposes and for publication.

Results: We present a middle-aged woman with a history of an autoimmune pancreatitis type 2 who had therapy-refractory TAC with Horner syndrome. Initial cerebral MRI showed only indistinct and unspecific signs of a pathologic process. A biopsy revealed a granulomatous hypophysitis. The symptoms disappeared after transsphenoidal subtotal resection of the pituitary mass and anti-inflammatory therapy.

Conclusions: This case elucidates that inflammatory pituitary diseases must be taken into account in case of atypical and refractory TAC, especially in patients with a history of autoimmune diseases. To our knowledge, the association between TAC accompanied by Horner syndrome and hypophysitis has not yet been described before. Neurol Neuroimmunol Neuroinflamm 2017;4:e332; doi: 10.1212/NXI.0000000000000332

\section{GLOSSARY}

AIP-II = autoimmune pancreatitis type 2; FT3 = free T3; HPF = high-power field; TAC = trigemino-autonomic cephalalgia; VAS $=$ visual analog scale.

Hypophysitis is a rare inflammatory disease of the pituitary gland with an incidence of 1 in 9 million. ${ }^{1}$ The pathogenesis of hypophysitis is not yet completely understood; however, in most cases, autoimmune inflammatory mechanisms seem to play a role. ${ }^{1}$ Up to the last years, only a rough classification into granulomatous, lymphocytic, or xanthomatous subtypes was used. Recently, 2 new types, the IgG4 antibody-related hypophysitis and the secondary medicationinduced hypophysitis, have been described. ${ }^{1,2}$ Typical clinical manifestations include endocrine abnormalities (e.g., diabetes insipidus, corticotroph deficiency, or hyperprolactinemia), visual disturbances, and headache. Oftentimes, patients describe migraine or tension-type-like headaches. ${ }^{3}$ By contrast, trigemino-autonomic cephalalgia (TAC) is rare. To our knowledge, a relationship of TAC to hypophysitis has been described only once before. ${ }^{4}$

Here, we report a patient with TAC refractory to medical therapy and Horner syndrome as a first sign of autoimmune hypophysitis.

PATIENT DESCRIPTION A 44-year-old woman with a history of an isolated biopsy-proven autoimmune pancreatitis type 2 (AIP-II) presented to our department with sharp left-sided occipital headache refractory to medical therapies. She reported nocturnal headache attacks with a duration of 1-2 hours and an

From the Department of Neurology (J.M., A.L.F., C.B., C.S., K.P., R.G., I.A.), Department of Radiology (C.L.), and Institute of Pathology (J.v.d.N.), Ruhr University Bochum; Department of Neurosurgery (I.K.-A., O.M.), and Institute of Neuropathology (J.v.d.N.), University of Duisburg-Essen; and Department of Neuropathology (R.B.), Friedrich-Alexander University Erlangen-Nürnberg (FAU), Germany.

Funding information and disclosures are provided at the end of the article. Go to Neurology.org/nn for full disclosure forms. The Article Processing Charge was paid by the authors.

This is an open access article distributed under the terms of the Creative Commons Attribution-NonCommercial-NoDerivatives License 4.0 (CC BY-NC-ND), which permits downloading and sharing the work provided it is properly cited. The work cannot be changed in any way or used commercially without permission from the journal. 

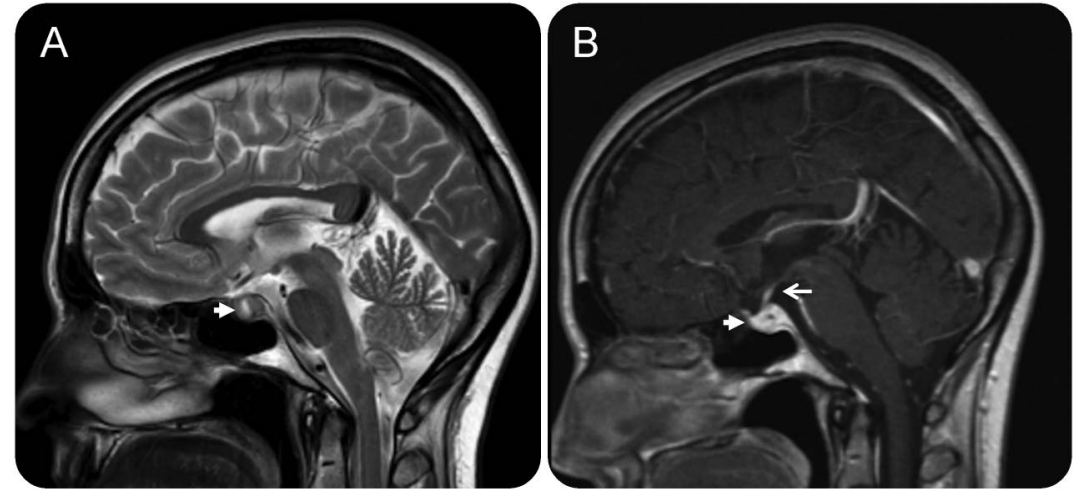

(A) Initial head MRI on admission; sagittal T2-weighted scan of the brain revealed an enlarged pituitary gland with a central T2-hyperintense abnormality (closed arrow). Immediate followup contrast-enhanced MRI (B) showed intensive enhancement of the pituitary gland and infundibular stalk (open arrow) suggestive of inflammation. Furthermore, the sellar mass is amplified and seems swollen. and duplex ultrasound of the cerebral arteries, were normal. An oxygen therapy with $4 \mathrm{~L} / \mathrm{min}$ during pain attacks was unsuccessful. Under symptomatic therapy with pregabalin $(150 \mathrm{mg} / \mathrm{d})$, duloxetine $(30 \mathrm{mg} / \mathrm{d})$, and ibuprofen (600 $\mathrm{mg}$ on demand), the headache resolved completely. However, ten days later, the patient was readmitted because of recurrence of the headache and a new right-sided Horner syndrome. Anhidrosis was not observed. Visual acuity, color vision, visual fields, fundoscopy, and remaining physical examinations were normal. Carotid artery dissection, brachial plexus, and lung apex pathologies were excluded. Reevaluation of the initial head MRI revealed a suspicious T2-hyperintense central lesion in an enlarged pituitary gland (figure 1A). A follow-up MRI including dynamic T1w-enhanced sequences of the pituitary gland confirmed signs of a pathologic intrasellar mass (figure 1B). On further history taking, the patient reported a premature menopause in her early forties. Laboratory investigation of the hypothalamo-pituitary axis revealed an increased prolactin (figure e-1 at Neurology.org/nn) and slightly decreased luteinizing and follicle-stimulating hormone levels. Both thyroid-stimulating hormone and free T3 (FT3) were decreased, and no antithyroid antibodies were detected. Moreover, water deprivation test, investigating posterior pituitary function, was pathologic. Antipituitary antibodies to anterior and posterior lobes and autoantibodies to vasopressin cells were negative. After a methylprednisolone pulse $(6 \times$ $125 \mathrm{mg}$ ), the headache and Horner syndrome disappeared. Two months later, a follow-up MRI yielded an increase of the sellar mass (figure 2, A-C). At the same time, the severe headache episodes recurred. After microneurosurgical resection of the pituitary mass lesion via transnasal-transsphenoidal approach, histology revealed a mixed cellular inflammatory lesion with eosinophilic granulocytes,
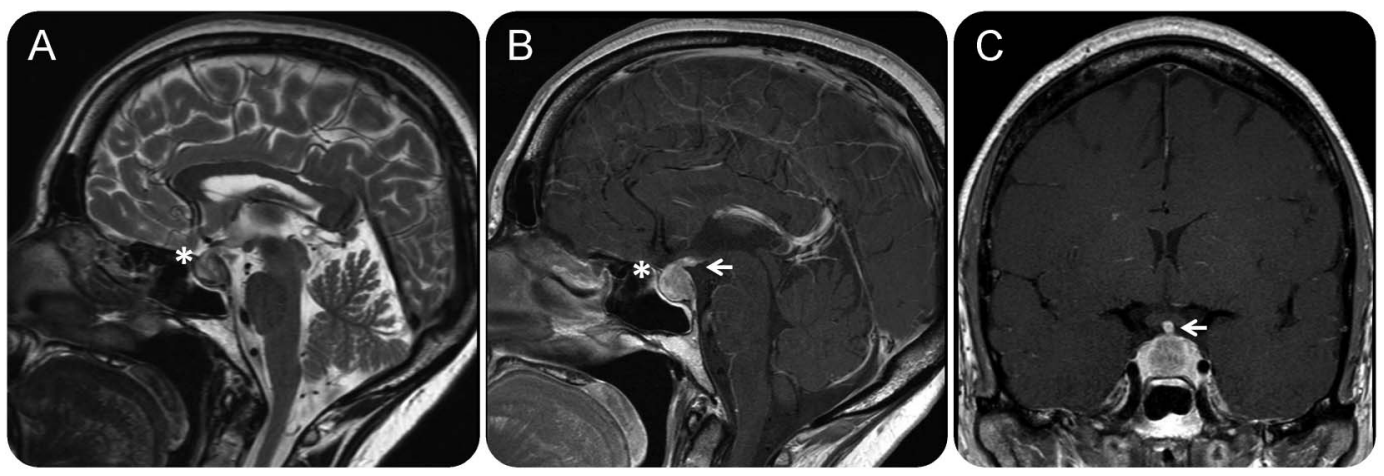

Two months later, a further MRI yielded progressive pituitary gland enlargement (asterisk) on sagittal T2-weighted images (A) with a thickened stalk (open arrow), both enhancing on a contrast-enhanced T1-weighted sequence (B: sagittal and C: coronal view; 2-mm slice thickness). 
giant cells, T- and B-lymphocytes, and groups of plasma cells. Histomorphology pointed to the existence of a granulomatous hypophysitis. Moreover, the number of IgG4-positive plasma cells focally reached $>10 / \mathrm{HPF}$ (high-power field), which is why an IgG4-associated hypophysitis was discussed. However, on the basis of IgG staining (figure 3), IgG4-related hypophysitis could not be diagnosed.

Postoperatively, the headache declined and remained remitted at the 6-month follow-up. Initially after surgery, the patient necessitated hydrocortisone replacement therapy (15 $\mathrm{mg}$ hydrocortisone/day) as well as $0.1 \mu \mathrm{g}$ desmopressin per day. The corticotroph hormone axis recovered within 6 months after surgery as did the gonadotroph hormone axis, so that the patient has regular menstrual cycles again after a 2 year-long disruption. Posterior pituitary function did not recover.

\section{Figure 3 Histopathologic findings of hypophysis biopsy}

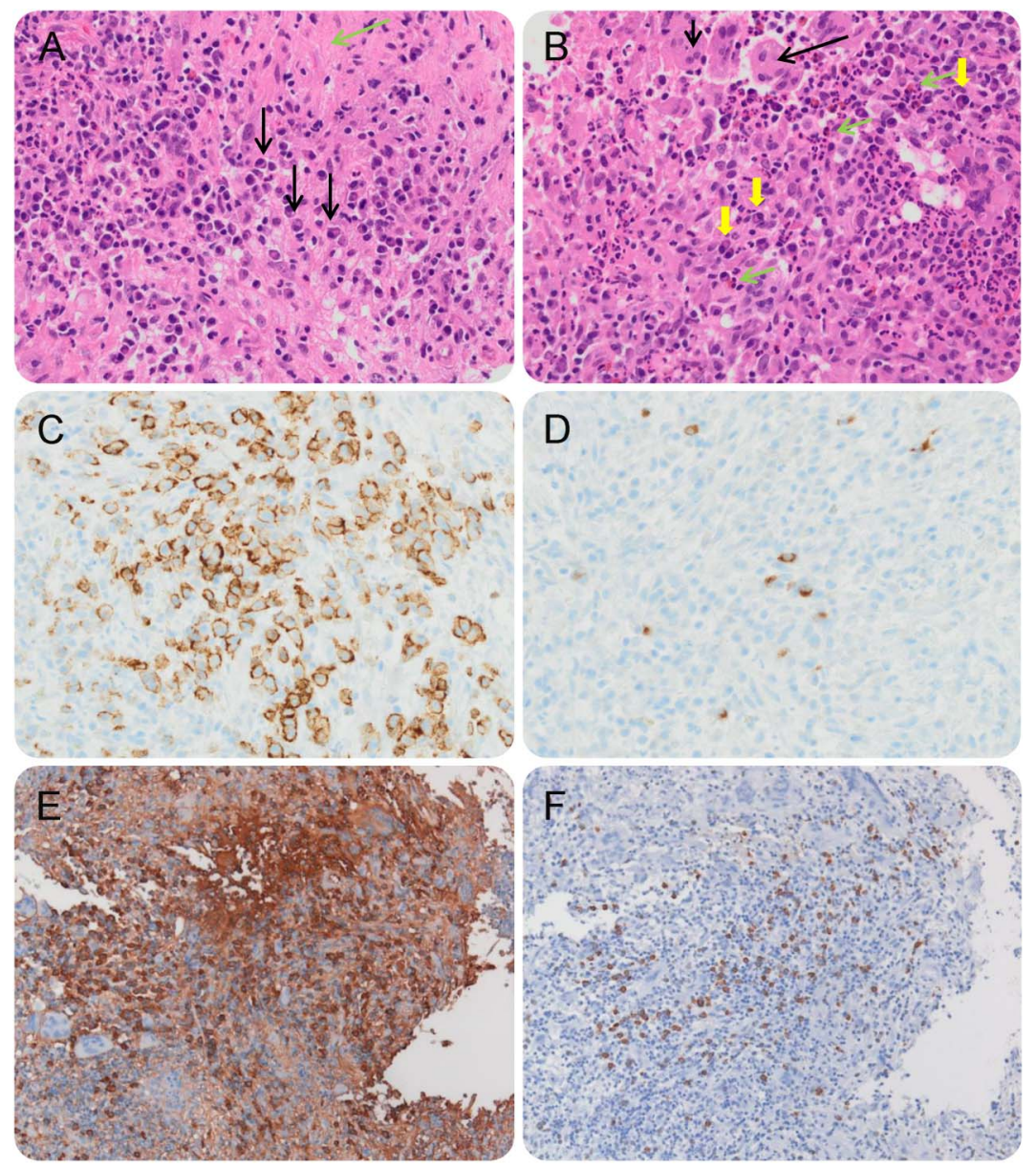

(A) Hematoxylin and eosin stain: black arrows mark plasma cells. The brightening cytoplasm represents Russell bodies as a sign for antibody production. The green arrow marks fibrosis. (B) Hematoxylin and eosin stain: black arrows mark multinucleated giant cells; yellow arrows mark plasma cells; and green arrows mark eosinophils. (C) Biopsy revealed groups of plasma cells (CD138) and (D) IgG4-positive cells in this region. The number of IgG4-positive cells elevated up to $>10 /$ HPF (high-power field). In (E) IgG immunostaining and (F) lgG4 immunsatining, an IgG4 $+/ \operatorname{lgG}+$ plasma cell ratio lower than $40 \%$ was observed.
DISCUSSION Here, we describe TAC and Horner syndrome caused by a granulomatous hypophysitis in association with an elevated number of IgG4positive plasma cells. IgG4+/IgG- ratio is low, and IgG4-positive plasma cell invasion can be seen as nonspecific. Therefore, this case does not satisfy the criteria for IgG4-related disease. Hypophysitis is a very rare neuroendocrine disease with many subtypes, some of which have only been described recently. Its early diagnosis is challenging because symptoms are often unspecific and standard cerebral MRI often lacks high-resolution imaging of the sellar region and thereby is not sensitive enough to capture subtle pituitary pathologies. Investigation of antipituitary autoantibodies does not have sufficient sensitivity and specificity for general use in diagnosis. ${ }^{1}$ In our case, TAC was the first sign of hypophysitis and developed before clear-cut endocrine abnormalities. Horner syndrome and central suppression of the thyroid axis over time lead to reevaluation of the initial head MRI and were crucial for diagnosis. Resolution of Horner syndrome after anti-inflammatory therapy and resolution of headache after resection of the hypophysis are in accordance with an inflammatory pituitary process and confirmed the secondary origin of TAC. ${ }^{5}$

Underlying pathologic mechanisms of TAC related to pituitary pathology remain unclear. TAC has been described before to be associated with pituitary adenomas. ${ }^{6}$ Cavernous sinus invasion and mechanic dural stretch due to a pituitary mass have been postulated as potential pathomechanisms of secondary headache related to pituitary pathology in the past. ${ }^{7}$ The only previously reported case of cluster headache due to granulomatous hypophysitis has been associated with a large pituitary lesion with suprasellar extension and consecutive bitemporal hemianopsia. ${ }^{4}$ Also, small noninvasive tumors of the pituitary as well as neuroendocrinologic abnormalities itself have been described to cause secondary TAC. ${ }^{6,89}$ By contrast, our patient developed TAC and Horner syndrome due to an inflammatory process, not due to an enlargement of the hypophysis. The role of neuroinflammation related to different types of primary headache such as migraine or cluster headache has been described extensively. ${ }^{5}$ Moreover, this case shows that an initial recovery of headache under symptomatic therapy does not exclude a secondary headache.

To our knowledge, hypophysitis and TAC in combination with Horner syndrome have not yet been described before. The presented case shows that patients with a history of autoimmune disease (here AIP-II) and newly occurring TAC should be thoroughly searched for pituitary pathology.

How a hypophysitis causes Horner syndrome is unclear. A potential explanation is the anatomical 
neighborhood between the pituitary gland on the one side and the sympathic root, sympathetic fibers of the trigeminal nerve, hypothalamic structures, and the dorsal longitudinal fasciculus as well as the medial forebrain bundle on the other side. ${ }^{10}$ Both tracks contain fibers of the central autonomic nervous system. However, in this case, no relevant enlargement of the hypophysis was shown. Therefore, the abovementioned explanations about the anatomical proximity of the involved structures do not explain the patients' symptoms. Hence, we suggest that autoimmune inflammation causes TAC and Horner syndrome. Our case shows that not only tumors but also autoimmune inflammation could cause disorders in these regions. ${ }^{5}$ Last, neuronal antibodies which target structures of the autonomic nervous system and the pituitary gland may cause Horner syndrome and TAC.

We present a case of granulomatous hypophysitis in association with TAC and Horner syndrome and establish a new differential diagnosis of Horner syndrome. Inflammatory pituitary diseases must be taken into account in case of atypical and refractory TAC, especially in patients with a history of autoimmune diseases. Repeated MRIs and appropriate endocrine tests may be needed to verify the diagnosis.

\section{AUTHOR CONTRIBUTIONS}

Jeremias Motte: data collection and drafting and revising the manuscript. Ilonka Kreitschmann-Andermahr: data collection and critical comments during manuscript revision. Anna Lena Fisse: drafting and revising the manuscript and critical comments during manuscript revision. Christian Börnke, Christoph Schroeder, and Kalliopi Pitarokoili: data collection and critical comments during manuscript revision. Oliver Müller: data collection. Carsten Lukas, Johannes van de Nes, and Rolf Buslei: data collection and critical comments during manuscript revision. Ralf Gold: critical comments during manuscript revision. Ilya Ayzenberg: data collection, drafting and revising the manuscript, and critical comments during manuscript revision.

\section{STUDY FUNDING}

No targeted funding.

\section{DISCLOSURE}

J. Motte reports no disclosures. I. Kreitschmann-Andermahr served on the scientific advisory board for Sandoz/Hexal PATRO and Ipsen Pharma $\mathrm{GmbH}$; receives travel funding and/or speaker honoraria from Ipsen, Pfizer, Novartis, Sandoz/Hexal, and Versartis; and received research support from Sandoz/Hexal, Versartis, and Ipsen Pharma. A.L. Fisse, C. Börnke, and C. Schroeder report no disclosures. K. Pitarokoili received travel funding and/or speaker honoraria from Biogen Idec and Bayer Schering Pharma. O. Müller served on the scientific advisory board for Medtronic and Johnson \& Johnson Codman Neuro and received travel funding and/or speaker honoraria from Medtronic and Johnson \& Johnson Codman Neuro. C. Lukas served on the scientific advisory board for Biogen Idec, Novartis, Genzyme, and Teva; received travel funding and/or speaker honoraria from Bayer Schering, Novartis, Boigen Idec, Teva, Genzyme, Sanofi, Phenox, and Stryker; and received research support from Merck Serono, Federal Ministry of Education and Research of the Federal Republic of Germany (BMBF), and Novartis Foundation. J. van de Nes and R. Buslei report no disclosures. R. Gold is on the editorial board of SAGE Journal, Aktuelle Neurologie, and Experimental Neurology. I. Ayzenberg reports no disclosures. Go to Neurology.org/nn for full disclosure forms.

Received October 7, 2016. Accepted in final form January 11, 2017.

\section{REFERENCES}

1. Carmichael JD. Update on the diagnosis and management of hypophysitis. Curr Opin Endocrinol Diabetes Obes 2012;19:314-321.

2. Leporati P, Landek-Salgado MA, Lupi I, Chiovato L, Caturegli P. IgG4-related hypophysitis: a new addition to the hypophysitis spectrum. J Clin Endocrinol Metab 2011;96:1971-1980.

3. Kreitschmann-Andermahr I, Siegel S, Weber Carneiro R, Maubach JM, Harbeck B, Brabant G. Headache and pituitary disease: a systematic review. Clin Endocrinol (Oxf) 2013;79:760-769.

4. Favier I, Haan J, Van Duinen SG, Ferrari MD. Typical cluster headache caused by granulomatous pituitary involvement. Cephalalgia 2007;27:173-176.

5. Buture A, Gooriah R, Nimeri R, Ahmed F. Current understanding on pain mechanism in migraine and cluster headache. Anesth Pain Med 2016;6:e35190.

6. Levy MJ, Matharu MS, Meeran K, Powell M, Goadsby PJ. The clinical characteristics of headache in patients with pituitary tumours. Brain 2005;128:1921-1930.

7. Forsyth PA, Posner JB. Headaches in patients with brain tumors: a study of 111 patients. Neurology 1993;43: $1678-1683$.

8. Abe T, Matsumoto K, Kuwazawa J, Toyoda I, Sasaki K. Headache associated with pituitary adenomas. Headache 1998;38:782-786.

9. May A. Cluster headache: pathogenesis, diagnosis, and management. Lancet 2005;366:843-855.

10. Shin RK, Cucchiara BL, Liebeskind DS, Liu GT, Balcer LJ. Pituitary apoplexy causing optic neuropathy and horner syndrome without ophthalmoplegia. J Neuroophthalmol 2003;23:208-210. 


\section{Neurology \\ Neuroimmunology \& Neuroinflammation}

Trigemino-autonomic headache and Horner syndrome as a first sign of granulomatous hypophysitis

Jeremias Motte, Ilonka Kreitschmann-Andermahr, Anna Lena Fisse, et al.

Neurol Neuroimmunol Neuroinflamm 2017;4;

DOI 10.1212/NXI.0000000000000332

This information is current as of February 14, 2017

Neurol Neuroimmunol Neuroinflamm is an official journal of the American Academy of Neurology.

Published since April 2014, it is an open-access, online-only, continuous publication journal. Copyright

Copyright $\odot 2017$ The Author(s). Published by Wolters Kluwer Health, Inc. on behalf of the American

Academy of Neurology. All rights reserved. Online ISSN: 2332-7812.

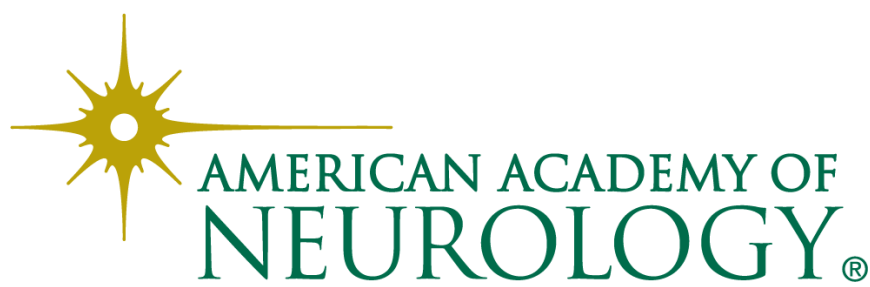




\section{Updated Information \& Services}

\section{Supplementary Material}

References

Subspecialty Collections

Permissions \& Licensing

Reprints including high resolution figures, can be found at: http://nn.neurology.org/content/4/3/e332.full.html

Supplementary material can be found at: http://nn.neurology.org/content/suppl/2017/05/05/4.3.e332.DC1

This article cites 10 articles, 0 of which you can access for free at: http://nn.neurology.org/content/4/3/e332.full.html\#\#ref-list-1

This article, along with others on similar topics, appears in the following collection(s):

All Clinical Neurology

http://nn.neurology.org//cgi/collection/all_clinical_neurology Autoimmune diseases

http://nn.neurology.org//cgi/collection/autoimmune_diseases

MRI

http://nn.neurology.org//cgi/collection/mri

Neuroendocrinology

http://nn.neurology.org//cgi/collection/neuroendocrinology

Secondary headache disorders

http://nn.neurology.org//cgi/collection/secondary_headache_disorders

Information about reproducing this article in parts (figures,tables) or in its entirety can be found online at:

http://nn.neurology.org/misc/about.xhtml\#permissions

Information about ordering reprints can be found online:

http://nn.neurology.org/misc/addir.xhtml\#reprintsus

Neurol Neuroimmunol Neuroinflamm is an official journal of the American Academy of Neurology.

Published since April 2014, it is an open-access, online-only, continuous publication journal. Copyright

Copyright $\odot 2017$ The Author(s). Published by Wolters Kluwer Health, Inc. on behalf of the American Academy of Neurology. All rights reserved. Online ISSN: 2332-7812.

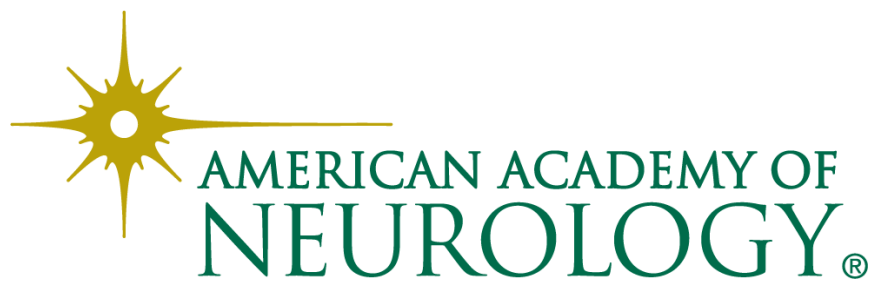

